\title{
KEEFEKTIFAN MODEL PEMBELAJARAN COOPERATIVE SCRIPT PADA MATERI BANGUN RUANG SISI LENGKUNG KELAS IX MTS DARUL ULUM SUMBER PENGANTIN JOGOROTO
}

\author{
Husnun Nadzifah \\ Pendidikan Matematika, Fakultas Ilmu Pendidikan, Universitas Hasyim Asy’Ari \\ nunazuph01@gmail.com \\ Siti Khabibah \\ Pendidikan Matematika, Fakultas Ilmu Pendidikan, Universitas Hasyim Asy’Ari \\ khabibah_khabibah@yahoo.com \\ Nihayatus Sa'adah \\ Pendidikan Matematika, Fakultas Ilmu Pendidikan, Universitas Hasyim Asy’Ari \\ nihayahsyakir@gmail.com
}

\begin{abstract}
Abstrak
Penelitian ini dilatarbelakangi oleh pembelajaran di MTs Darul Ulum Sumber Pengantin Jogoroto yang masih berpusat pada guru seperti ceramah, dan tanya jawab. Pembelajaran tersebut menyebabkan peserta didik mudah bosan sehingga tidak tertarik untuk mengikuti proses pembelajaran dengan sungguh-sungguh. Hal ini juga menjadikan peserta didik kurang antusias dalam pembelajaran sehingga hasil belajar peserta didik masih belum mencapai standar yang ditentukan. Tujuan dari penelitian ini untuk mendeskripsikan keefektifan model pembelajaran cooperative script pada materi bangun ruang sisi lengkung yang ditinjau dari respon dan hasil belajar peserta didik. Rancangan penelitian ini menggunakan PreExperimental dengan desain One-Shot Case Study sedangkan metode penelitian menggunakan analisis deskriptif dengan pendekatan kuantitatif. Hasil penelitian ini menunjukkan bahwa pada penerapan model pembelajaran cooperative script menghasilkan data: (1) Hasil belajar peserta didik yang tuntas ada 9 peserta didik, sedangkan yang tidak tuntas 13 peserta didik, maka persentase secara klasikal nilainya 40.9\%. (2) Respon peserta didik terhadap model pembelajaran cooperative script adalah positif yang ditunjukkan bahwa terdapat 6 pernyataan yang memperoleh tanggapan positif, dan persentase respon positif tersebut adalah $60 \%$. Dari uraian tersebut dapat disimpulkan bahwa penerapan model pembelajaran cooperative script pada materi bangun ruang sisi lengkung tidak efektif.
\end{abstract}

Kata Kunci: Keefektifan, Cooperative Script, Bangun Ruang Sisi Lengkung.

\begin{abstract}
This research is held by the fact that the teacher centered learning process such as lecturing and questioning still used in MTs Darul Ulum Sumber Pengantin Jogoroto. This type of learning makes students bored easily so they are not interested in participating in the learning process seriously. This also makes students still have not reached the specified standard. The purpose of this study was to describe the effectiveness of the cooperative script learning model in solid geometry material reviewed by the responses and learning outcomes of students. This research design uses Pre-Experimental with One-Shot Case Study design, while the research method used descriptive analysis with quantitative approach. The results of this study indicated that the application of the cooperative script learning model produced data: (1) The student's learning outcomes who completed were 9 students, while those who are not completed are 13 students, then the classical achievment value was $40.9 \%$. (2) The response of students to the cooperative script learning model was positive, which was indicated that there were 6 statements that got positive responses, and the persentation of the positive responses was 60\%. From this description, it could be concluded that the application of the cooperative script learning model on the solid geometry materials was not effective.
\end{abstract}

Keywords: Effectiveness, Cooperative Script, Solid Geometry. 


\section{PENDAHULUAN}

Pendidikan merupakan salah satu faktor penting dalam perkembangan peserta didik. Pendidikan bisa berupa bimbingan yang diberikan dari orang yang lebih paham untuk seseorang yang belum paham demi mencapai keberhasilan dalam hidupnya. Perkembangan anak melalui pendidikan yang berkualitas akan membentuk masa depan yang bagus untuk anak tersebut. Hal tersebut sejalan dengan apa yang dikatakan Feni (2014) bahwa pendidikan merupakan bimbingan diberikan oleh orang dewasa terhadap perkembangan anak untuk mencapai kedewasaannya dengan tujuan agar anak tersebut cukup cakap dalam melaksanakan tugas hidupnya sendiri tidak dengan bantuan orang lain.

Pendidikan di sekolah merupakan pembelajaran formal yang terencana. Pada proses pembelajaran berlangsung, pendidik dan peserta didik harus bekerja sama demi tercapainya tujuan dan hasil dari proses pembelajaran yang maksimal. Peserta didik dapat mengembangkan potensi diri dengan pembentukan sikap, keterampilan, kecerdasan, dan berwawasan luas. Untuk mencapai keberhasilan yang maksimal, pendidik perlu menggunakan metode pembelajaran yang cocok dalam proses belajar. Hal tersebut sejalan dengan pendapat Djamarah \& Zain (2010) yang mengatakan bahwa kedudukan metode adalah sebagai alat motivasi ekstrinsik, strategi pembelajaran serta alat untuk mencapai tujuan belajar yaitu ketuntasan hasil belajar. Oleh karena itu, terciptalah berbagai macam model pembelajaran agar dapat menyesuaikan dengan peserta didik sebagai bentuk usaha meningkatkan kualitas belajar peserta didik.

Menurut Trianto (2010) model pembelajaran adalah suatu perencanaan sebagai pedoman dalam merencakan pembelajaran di kelas. Berdasarkan pendapat tersebut dapat dikatakan bahwa model pembelajaran merupakan rangkaian strategi pembelajaran yang dibuat sebagai pengarahan bagi pendidik dan peserta didik dari sebelum berlangsungnya proses pembelajaran, sedang dilakukannya proses pembelajaran, dan setelah proses pembelajaran berlangsung. Pemilihan model pembelajaran harus teliti dan tepat agar proses belajar berjalan aktif, efektif, efisien, dan memperoleh hasil belajar yang maksimal. Hal tersebut sejalan dengan pendapat Fathurrahman \& Sutikno (2010) bahwa makin tepat metode pembelajaran yang digunakan oleh pendidik dalam mengajar, diharapkan semakin efektif pula pencapaian tujuan pembelajaran.

Berdasarkan hasil wawancara dengan salah satu guru matematika di MTs Darul Ulum Sumber Pengantin bahwa dalam proses belajar matematika, kondisi peserta didik terdapat 2 golongan, yaitu (1) peserta didik yang benar-benar ingin memahami ilmunya dia serius, dan (2) peserta didik yang tidak tertarik dia tidak memperhatikan pembelajaran dengan serius.

Setelah dilakukan evaluasi dengan tanya jawab antara pendidik dan peserta didik, ternyata peserta didik merasa kesulitan terhadap mata pelajaran matematika. Adapun alasan mereka merasa kesulitan belajar matematika yaitu proses pembelajaran matematika yang monoton, mata pelajaran matematika terdapat banyak rumus, peserta didik merasa kurang berani dalam menyampaikan jawaban karena takut salah, sehingga peserta didik menjadi pasif dalam proses pembelajaran. Jika peserta didik pasif, pendidik akan merasa kesulitan untuk mengetahui kemampuan peserta didik dalam memahami materi. Sering terjadi peserta didik kesulitan dalam menyelesaikan soal latihan dikarenakan banyaknya rumus yang membuat peserta didik keliru atau lupa rumus yang akan digunakan, sehingga ketuntasan hasil belajar masih rendah.

Kemudian untuk menghasilkan ketuntasan belajar yang maksimal, pendidik perlu menerapkan model pembelajaran yang menyenangkan sehingga peserta didik merasa nyaman, tidak mudah bosan, dan lebih tertarik untuk belajar matematika. Peserta didik juga menjadi lebih percaya diri dan aktif dalam pembelajaran seperti bekerja sama dalam kelompok, bertukar pikir dan pendapat antar teman, belajar menggali dan menyampaikan materi sehingga peserta didik akan terpacu untuk 
mengingat dan memahami materi yang telah dipelajari atau didiskusikan. Peserta didik yang mendengarkan dan menyampaikan materi dan rumus secara berulang-ulang maka peserta didik akan semakin mudah memahami dan mengingat materi tersebut. Peserta didik diberikan tugas menggambar bangun ruang beserta jaring-jaringnya agar lebih mudah dalam memahami materi dan rumus bangun ruang tersebut. Berdasarkan hal tersebut, model pembelajaran kooperatif merupakan model pembelajaran yang cocok karena menurut Rofiq (2010) model pembelajaran kooperatif memiliki beberapa kelebihan yaitu: (1) Dapat meningkatkan prestasi hasil belajar peserta didik, (2) Mampu memperdalam pemahaman peserta didik, (3) Dianggap menyenangkan bagi peserta didik, (4) Membantu peserta didik dalam mengembangkan kemampuan kepemimpinan, (5) Membantu peserta didik untuk mengembangkan sikap saling memiliki satu sama lain dan lain sebagainya.

Salah satu tipe model pembelajaran kooperatif adalah model pembelajaran cooperative script, peserta didik bekerja berpasangan dan bergantian dalam menyampaikan bagian-bagian dari materi yang telah dipelajari secara berkelompok (Shoimin, 2014) menyampaikan bahwa salah satu model pembelajaran yang dapat meningkatkan daya ingat peserta didik adalah pembelajaran dengan model cooperative script. Berdasarkan pendapat tersebut menunjukkan bahwa model pembelajaran cooperative script memiliki ciri khas tersendiri yaitu mampu membantu peseta didik untuk meningkatkan daya pemahaman serta ingatannya. Daya ingat peserta didik pada materi yang diperoleh sebelumnya berperan penting untuk memudahkan materi selanjutnya. Apalagi dalam matematika peserta didik akan memahami materi demi materi, sehingga peserta didik akan lebih mudah dalam memahami materi selanjutnya. Jadi, solusi dari masalah yang akan diselesaikan dengan menerapkan model pembelajaran cooperative script diharapkan peserta didik percaya diri dalam berpendapat maupun bertanya untuk memahami materi dan mengulang-ulang rumus agar pemahaman materi serta rumus dapat diingat terusnya.

Bangun ruang sisi lengkung merupakan salah satu materi pada mata pelajaran matematika yang penerapannya sering kita ketahui dalam kehidupan seharihari. Meski sering ditemukan dalam kehidupan sehari-hari, peserta didik sering melakukan kesalahan, merasa kesulitan dalam mengerjakan latihan soal. Nuraida (2017) menyampaikan bahwa penyebab kesalahan peserta didik dalam mengerjakan soal materi bangun ruang sisi lengkung salah satunya adalah peserta didik lupa rumus yang harus dipakai, tertukar antara rumus tabung dan rumus kerucut.

Berdasarkan uraian di atas, maka perlu diadakan penelitian menggunakan model pembelajaran cooperative script pada materi bangun ruang sisi lengkung untuk menciptakan proses pembelajaran yang nyaman, aktif, efektif demi mencapai respon positif dari peserta didik serta hasil belajar yang maksimal dalam belajar bangun ruang sisi lengkung. Pembelajaran tersebut diharapkan agar peserta didik mendapatkan kesempatan utnuk membangun pengetahuannya dan memahami materi dengan baik sehingga mampu menghasilkan respon positif dan hasil belajar yang tuntas.

\section{METODE}

Penelitian ini menggunakan jenis penelitian kuantitatif dengan metode analisis deskriptif kuantitatif. Rancangan penelitian yang digunakan ialah preExperimental design dengan bentuk desain One-Shot Case Study. Desain penelitian One-Shot Case Study merupakan penelitian dengan pengambilan data dari satu kelompok yang diberikan perlakuan (treatment) kemudian diadakan posttest dan hasil posttest tersebut akan diobservasi dengan berpedoman kriteria ketentuan minimum (KKM). Satu kelompok tersebut diberikan perlakukan pembelajaran dengan menggunakan model cooperative script.

Populasi dari penelitian ini yaitu peserta didik kelas IX MTs Darul Ulum Sumber Pengantin dengan sampel 
pengambilan data peserta didik kelas IX A yang berjumlah 22 anak. Proses Pengambilan dilakukan pada tanggal 17-18 Juli 2021, meskipun adanya pandemi covid19 namun pembelajaran tetap dilakukan secara tatap muka dengan memperhatikan protokol kesehatan.

\section{HASIL DAN PEMBAHASAN}

Pelaksanaan pengambilan data dimulai pada hari Sabtu tanggal 17 Juli 2021. Sebelum memulai pembelajaran di kelas, guru mata pelajaran memperkenalkan peneliti kepada peserta didik dan menjelaskan bahwa hari ini peneliti akan mengadakan penelitian untuk skripsi sebagai syarat kelulusan sarjana strata 1 . Pada pertemuan ini, peneliti membuka pembelajaran dengan doa bersama-sama dan dilanjutkan mengabsen kehadiran peserta didik. Selanjutnya pemberian apersepsi tentang pokok bahasan bangun datar dan bangun ruang sisi datar. Sesuai dengan rencana pelaksanaan pembelajaran yang telah dibuat, diantaranya ialah peneliti menjelaskan sedikit pokok bahasan bangun ruang sisi lengkung dan menjelaskan model pembelajaran apa yang akan dilakukan. Selepas itu pembagian kelompok, terdapat 3 kelompok yang masing-masing merundingkan peran dalam kelompok yaitu pembicara atau pendengar. Masing-masing kelompok berdiskusi materi dan gagasan apa saja yang akan disampaikan kepada pendengar lain dan tugas pendengar mencatat apa saja yang ia terima dari pembicara dan memberikan pendapat, saran, maupun pertanyaan kepada pembicara. Setelah semua kelompok telah menyampaikan materi dan gagasannya, pendidik memberikan masukan dan penguatan materi tersebut serta membuat kesimpulan bersama peserta didik. Kemudian pendidik membimbing peserta didik mencatat di buku masing-masing secara lengkap yang diterima dari semua pembicara serta dari penguatan pendidik dan kesimpulan bersama. Di akhir proses pembelajaran peneliti memberikan lembar angket respon peserta didik guna untuk mengetahui tanggapan sesudah melalui pembelajaran dengan menggunakan model cooperative script.

\section{Data Hasil Belajar}

Pada hari Minggu tanggal 18 Juli 2021, peneliti melakukan tes untuk memperoleh data hasil belajar peserta didik. Pada saat itu peneliti menyampaikan bahwa akan dilakukan posttest dengan 5 butir soal uraian,diperoleh data hasil belajar sebagai berikut:

Tabel 1. Analisis Hasil Belajar

\begin{tabular}{|c|c|c|c|}
\hline No. & Nama & Nilai & Keterangan \\
\hline 1 & AINR & 80 & Tuntas \\
\hline 2 & ANR & 45 & Tidak Tuntas \\
\hline 3 & DA & 60 & Tidak Tuntas \\
\hline 4 & HK & 70 & Tidak Tuntas \\
\hline 5 & ITN & 40 & Tidak Tuntas \\
\hline 6 & MABA & 40 & Tidak Tuntas \\
\hline 7 & MMA & 80 & Tuntas \\
\hline 8 & MRA & 80 & Tuntas \\
\hline 9 & MTR & 80 & Tuntas \\
\hline 10 & MAMI & 50 & Tidak Tuntas \\
\hline 11 & EAS & 60 & Tidak Tuntas \\
\hline 12 & NLR & 60 & Tidak Tuntas \\
\hline 13 & PNI & 65 & Tidak Tuntas \\
\hline 14 & PNA & 65 & Tidak Tuntas \\
\hline 15 & RNA & 60 & Tidak Tuntas \\
\hline 16 & RRD & 50 & Tidak Tuntas \\
\hline 17 & SFZ & 60 & Tidak Tuntas \\
\hline 18 & SA & 75 & Tuntas \\
\hline 19 & ZS & 75 & Tuntas \\
\hline 20 & MFK & 75 & Tuntas \\
\hline 21 & ANA & 75 & Tuntas \\
\hline 22 & SD & 75 & Tuntas \\
\hline
\end{tabular}

Berdasarkan tabel tampak bahwa peserta didik yang tuntas lebih sedikit dibandingkan dengan yang tidak tuntas. Terdapat 9 per 22 peserta didik yang hasil belajarnya tuntas, 13 peserta didik tidak tuntas. Persentase secara klasikal hasil belajar pada penelitian ini memperoleh 40.9\%. Artinya persentase hasil belajar tersebut kurang dari $75 \%$, jadi dapat diambil kesimpulan bahwa penerapan pembelajaran dengan menggunakan model cooperative script pada pokok bahasan bangun ruang sisi lengkung tidak efektif ditinjau dari hasil belajar.

\section{Data Hasil Angket Respon}

Dalam penelitian ini, peneliti memberikan 10 pernyataan untuk melihat tanggapan peserta didik. Data hasil angket respon peserta didik ialah sebagai berikut: 
Tabel 2. Analisis Respon

\begin{tabular}{|c|c|c|c|}
\hline Pernyataan & \%Ya & \% Tidak & Ket. \\
\hline 1 & $77.2 \%$ & $18.2 \%$ & Positif \\
\hline 2 & $40.9 \%$ & $59 \%$ & Positif \\
\hline 3 & $27.2 \%$ & $77.2 \%$ & Negatif \\
\hline 4 & $40.9 \%$ & $59 \%$ & Positif \\
\hline 5 & $72.7 \%$ & $27.2 \%$ & Positif \\
\hline 6 & $54.5 \%$ & $36.3 \%$ & Negatif \\
\hline 7 & $59 \%$ & $50 \%$ & Positif \\
\hline 8 & $50 \%$ & $45.4 \%$ & Negatif \\
\hline 9 & $50 \%$ & $54.5 \%$ & Negatif \\
\hline 10 & $45.4 \%$ & $54.5 \%$ & Positif \\
\hline
\end{tabular}

Berdasarkan tabel terlihat bahwa terdapat pernyataan yang memperoleh tanggapan positif maupun negatif. Terdapat 6 pernyataan yang memperoleh tanggapan positif yang ditunjukkan pada poin pertanyaan no.1, 2, 4, 5, 7, dan 10. Hal ini menunjukkan bahwa peserta didik merasa senang pada saat pembelajaran cooperative script karena tanggapan positif lebih besar dari tanggapan negatif. Respon positif tersebut juga terlihat pada saat proses pembelajaran berlangsung mereka lebih berani menyampaikan pendapat dan bertanya ke teman-teman yang lain, hal tersebut sesuai dengan tanggapan peserta didik pada pernyataan no. 5. Jadi, pada penelitian ini dapat disimpulkan bahwa pembelajaran dengan menerapkan model pembelajaran cooperative script pada materi bangun ruang sisi lengkung kelas IX A MTs Darul Ulum Sumber Pengantin Jogoroto dapat dikatakan efektif ditinjau dari hasil respon peserta didik terhadap model pembelajaran cooperative script.

Penelitian ini bertujuan guna mendeskripsikan keefektifan pembelajaran dengan menggunakan model cooperative script. Indikator keefektifan dalam penelitian ini ada dua yaitu respon dan hasil belajar peserta didik. Apabila terdapat indikator yang tidak efektif, maka pembelajaran tidak dapat dikatakan efektif. Berdasarkan hasil penelitian ini, hasil belajar peserta didik tidak efektif karena belum mencapai ketentuan dari peneliti sehingga pada penelitian ini model pembelajaran yang diterapkan tidak efektif.

Model pembelajaran tidak efektif disebabkan karena kebiasaan peserta didik mencotek temannya sehingga peserta didik kurang mandiri dalam menyelesaiakan soal, perihal ini sependapat dengan Wulandari (2014) bahwa manfaat kemandirian belajar sangat berpengaruh bagi kemampuan dalam memecahkan masalah, peserta didik lebih mudah mengembangkan kemampuannya. Ketidakefektifan juga dipengaruhi oleh peneliti yang menerapkan model pembelajaran cooperative script tidak sesuai sintaks yaitu kelompok dibagi menjadi 3, tiap kelompok terdiri antara 7 sampai 8 anak. Padahal langkah-lanhkah model pembelajaran cooperative script menurut Huda (2013) salah satunya adalah Guru membagi kelompok untuk berpasangan yang artinya tiap kelompok terdiri dari 2 peserta didik.

\section{SIMPULAN}

Simpulan yang diperoleh dari hasil penelitian dan pembahasan yang telah disampaikan ialah persentase hasil belajar secara klasikal yang diperoleh peserta didik setelah diberikan perlakuan pembelajaran dengan menggunakan model cooperative script di kelas IX A MTs Darul Ulum Sumber Pengantin pada materi bangun ruang sisi lengkung ialah 40.9\%. Dari 22 peserta didik, hanya 9 anak yang tuntas. Persentase hasil belajar secara klasikal kurang dari $75 \%$, maka hasil belajar peserta didik secara klasikal tidak tuntas. Dengan begitu, penerapan pembelajaran dengan menggunakan model cooperative script dinyatakan tidak efektif ditinjau dari hasil belajar peserta didik.

Respon peserta didik mengenai pembelajaran dengan menerapkan model cooperative script di kelas IX A MTs Darul Ulum Sumber Pengantin pada materi bangun ruang sisi lengkung adalah $60 \%$. Dari 10 pernyataan terdapat 6 pernyataan yang memperoleh respon positif. Persentase respon peserta didik tersebut lebih dari atau sama dengan 50\%, maka secara klasikal respon peserta didik terhadap pembelajaran dengan menggunakan cooperative script bernilai positif. Dengan demikian, penerapan model pembelajaran cooperative script dapat dinyatakan efektif ditinjau dari hasil respon peserta didik. 


\section{DAFTAR PUSTAKA}

Djamarah, S. Bahri \& Zain, A. 2010. Strategi Belajar Mengajar. Jakarta: PT Rineka Cipta.

Fathurrahman, P. \& Sutikno, M. Sobry. 2010. Strategi Belajar Mengajar. Bandung: PT Refika Aditama.

Feni. 2014. Pendidikan dan Perilaku Kesehatan. Jakarta: PT Rineka Cipta.

Nuraida, I. 2017. Analisis Kesalahan Penyelesaian Soal Bangun Ruang Sisi Lengkung Siswa Kelas IX SMP Negeri 5 Kota Tasikmalaya. TEOREMA:
Jurnal Teori dan Riset Matematika.1(2).25-30.

Rofiq, M. N. 2010. Pembelajaran Kooperatif (Cooperative Learning) dalam Pengajaran Pendidikan Agama Islam. Jurnal FALASIFA, 1(1).

Shoimin, A. 2014. 68 Model Pembelajaran Inovatif dalam Kurikulum 2013. Yogyakarta: Arruzz Media.

Trianto. 2010. Model Pembelajaran Terpadu, Konsep, Strategi, dan Implementasinya dalam KTSP. Jakarta: Bumi Aksara. 